Piotr Czarny

\title{
Interpretacja art. 15 ust. 1 regulaminu Sejmu ${ }^{1}$
}

\author{
Interpretation of Article 15 para. 1 of the Standing Orders of the Sejm
}

$\mid$

The opinion presents the interpretation of the definition of "parliamentary group representing a separate electoral list on the day of the start of the Sejm's term". The conditions that all Deputies' associations have to meet in order to fall into this category have been indicated. Meeting such conditions is necessary for obtaining the right to participate of a representative of the group in sittings of the Council of Seniors. The need to amend the interpreted provision of the Standing Orders of the Sejm, in order to adapt it to relevant provisions of electoral law, has been also signalled.

Keywords: parliamentary group, Council of Seniors, Standing Orders of the Sejm

\begin{abstract}
W opinii przedstawiono interpretację definicji „koła parlamentarnego reprezentującego w dniu rozpoczęcia kadencji Sejmu osobną listę wyborczą". Wskazano warunki, jakie łącznie muszą spełnić zrzeszenia, aby podlegały tej kategorii. Spełnienie tych warunków jest konieczne dla udziału przedstawiciela określonego koła w posiedzeniach Konwentu Seniorów. Zasygnalizowano potrzebę dokonania nowelizacji interpretowanego przepisu regulaminu Sejmu w celu dostosowania go do obowiązujących przepisów prawa wyborczego.
\end{abstract}

Słowa kluczowe: koło poselskie, Konwent Seniorów, regulamin Sejmu

Doktor nauk prawnych, starszy wykładowca -

Uniwersytet Jagielloński w Krakowie, Wydział Prawa i Administracji, Katedra Prawa

Konstytucyjnego, KRAKÓW, POLSKA •

piotr.czarny@neostrada.pl • https://orcid.org/0000-0002-6558-1075

\section{Ustalenia wstępne}

Niniejsza opinia prawna dotyczy wykładni określonej części art. 15 ust. 1 regulaminu Sejmu oraz odpowiedzi na pytanie o interpretację pojęcia „koła parlamentarne reprezentujące w dniu rozpoczęcia kadencji Sejmu osobną listę wyborczą", a także ocenę - w kontekście członkostwa w Konwencie Seniorów - sytuacji, w której dany komitet wyborczy wprowadza do Sejmu mniej niż 15 posłów, a na początku kadencji (pytanie dodatkowe: kiedy, czy w dniu rozpoczęcia pierwszego posiedzenia, czy, jeśli to możliwe, wcześniej) posłowie ci informują Marszałka o utworzeniu dwóch (lub nawet więcej) kół. Problem praktyczny, jaki powstaje w takim wypadku, polega na tym, czy któreś z nich (a jeśli tak, to dlaczego) uważać można za uprawnione do udziału jego przedstawiciela w posiedzeniach Konwentu Seniorów.

1 Opinia prawna dotyczaca interpretacji art. 15 ust. 1 regulaminu Sejmu sporządzona 8 listopada 2019 r. na zlecenie zastępcy Szefa Kancelarii Sejmu; BAS-WAKiU 2252/19. 
Zgodnie $z$ art. 15 ust. 1 regulaminu Sejmu (t.j. M.P. 2012, poz. 32, ze zm.) w skład Konwentu Seniorów wchodzą: Marszałek, wicemarszałkowie, przewodniczący lub wiceprzewodniczący klubów oraz przedstawiciele porozumień, o których mowa w art. 8 ust. 5, a także klubów parlamentarnych, jeśli reprezentują co najmniej 15 posłów, oraz kół parlamentarnych reprezentujących w dniu rozpoczęcia kadencji Sejmu osobną listę wyborczą. Niniejsza opinia dotyczy wyłącznie ostatniej z wymienionych w tym przepisie kategorii członków Konwentu Seniorów. Oczywiste jest przy tym, że koło liczyć musi co najmniej trzech posłów (art. 8 ust. 3 regulaminu Sejmu).

Należy podkreślić, że końcowa część art. 15 ust. 1 została wprowadzona w uchwale Sejmu z 28 października 1997 r. w sprawie zmiany regulaminu Sejmu RP (M.P. nr 80, poz. 779), która weszła w życie z dniem jej podjęcia (art. 3). Można zwrócić uwagę, że postanowienia analogicznego do regulacji zawartej w art. 15 ust. 1 in fine regulaminu Sejmu nie ma w regulaminie Senatu.

\section{Uzasadnienie i ustalenia szczegółowe}

W pierwszej kolejności należy zauważyć, że wykładnia art. 15 ust. 1 in fine regulaminu Sejmu jest utrudniona z uwagi na wysoce niejednoznaczny sposób sformułowania, co podaje w wątpliwość wyniki wykładni językowej i systemowej. Świadczy o tym przede wszystkim użycie wyrażenia „koła parlamentarne”, co sugerowałoby, że chodzi o zrzeszenia parlamentarzystów, o których mówi art. 17 ust. 3 ustawy z 9 maja 1996 r. o wykonywaniu mandatu posła i senatora (t.j. Dz.U. 2018, poz. 1799, ze zm.). Zgodnie z tym przepisem posłowie wraz z senatorami mogą tworzyć wspólne kluby, koła lub zespoły parlamentarne. Natomiast posłowie (sami posłowie) tworzyć mogą m.in. koła poselskie (art. 17 ust. 1 ustawy o wykonywaniu mandatu, art. 8 ust. 1 i 3 regulaminu Sejmu), które są zatem formalnie pewnym odrębnym od kół parlamentarnych rodzajem zrzeszeń. Jednak ściśle logiczno-językowa interpretacja prowadziłaby do absurdalnych konsekwencji. Otóż w wyborach do Senatu komitety wyborcze zgłaszać mogą tylko jednego kandydata w okręgu wyborczym (art. 264 ustawy z 5 stycznia 2011 r. - Kodeks wyborczy, t.j. Dz.U. 2019, poz. 684, ze zm.). Stąd też senator z natury rzeczy nie może „reprezentować” żadnej listy wyborczej. Aby uniknąć w związku z tym sytuacji, w której art. 15 ust. 1 in fine regulaminu Sejmu jest tzw. normą pustą (tj. nie może znaleźć zastosowania do żadnej sytuacji faktycznej), przyjąć należy, że odnosi się on w istocie do kół poselskich, a więc formuły koła parlamentarne należy używać w specyficznym znaczeniu, innym niż wynikające $z$ ustawy o wykonywaniu mandatu. Założenie to nie oznacza, że również wspólne koła poselsko-senatorskie nie mogą korzystać z uprawnienia do wskazywania swojego przedstawiciela w Konwencie Seniorów. Będzie tak w sytuacji, gdy wszyscy posłowie członkowie określonego koła „reprezentują osobną listę 
wyborczą" i spełnione zostaną inne warunki, takie jak w przypadku kół poselskich. Dodać należy, że ukształtowana praktyka parlamentarna wskazuje, że do utworzenia koła parlamentarnego wystarczy przynależność do niego minimalnej liczby posłów lub senatorów koniecznej dla założenia koła poselskiego lub senatorskiego (oraz co najmniej jednego członka drugiej z izb). Niezależnie od tego, czy praktyka ta jest prawidłowa, oznacza to, że może powstać sytuacja, w której koło parlamentarne składa się tylko z 1 lub 2 posłów oraz z co najmniej trzech senatorów, choć przynajmniej na początku kadencji jest to mało prawdopodobne. W takiej szczególnej sytuacji zasada równego traktowania (art. 32 ust. 1 Konstytucji) wymaga jednak, aby członkostwo przedstawiciela takiego koła w Konwencie Seniorów ograniczone było do takich zrzeszeń, do których należy co najmniej 3 posłów.

Po drugie, formuła mówiąca o reprezentowaniu osobnej listy wyborczej jest również w sensie prawnym wysoce niejasna. Wydaje się oczywiste, że nawiązywać ona powinna do prawa wyborczego. Jednak Kodeks wyborczy posługuje się w odniesieniu do wyborów do Sejmu pojęciem listy kandydatów zgłoszonych przez komitety wyborcze w poszczególnych okręgach wyborczych (zob. art. 209 i nast. Kodeksu wyborczego). Należy też podkreślić, że pojęcia „lista wyborcza" nie używała obowiązująca w 1997 r. (a więc w czasie, kiedy weszła w życie analizowana zmiana regulaminu Sejmu) ustawa z 28 maja 1993 r. - Ordynacja wyborcza do Sejmu Rzeczypospolitej Polskiej (Dz.U. nr 45 poz. 205, ze zm.), która rozróżniała listy okręgowe i ogólnopolskie kandydatów na posłów (art. 2). Poza tym zgodnie z językowym znaczeniem słowa „reprezentować” oznacza ono (przynajmniej w podstawowym znaczeniu): występowanie $w$ imieniu i na rzecz jakiejś osoby, grupy osób, organizacji lub instytucji ${ }^{2}$. W tym dosłownym sensie koło poselskie (czy też koło parlamentarne) nie może reprezentować listy wyborczej, bo nie można bliżej ustalić podmiotu reprezentowanego. Nie wiadomo, czy chodzi tu o występowanie w imieniu wyborców, którzy oddali głos na określoną listę, ogółu kandydatów umieszczonych na liście, czy też może komitetu wyborczego, który ją zgłosił. Samą listę wyborczą można byłoby ewentualnie uważać za instytucję prawną, ale niemożliwe jest jej reprezentowanie w podanym wcześniej znaczeniu.

W tym kontekście zasygnalizować tylko należałoby potrzebę dokonania nowelizacji regulaminu Sejmu i dostosowania art. 15 ust. 1 w części końcowej do obowiązujących norm Kodeksu wyborczego. Inną możliwość sprecyzowania treści tego przepisu stanowi podjęcie przez Prezydium Sejmu uchwały interpretacyjnej na podstawie art. 12 pkt 3 regulaminu Sejmu.

Pewnych (aczkolwiek niepełnych) wskazań dla interpretacji art. 15 ust. 1 in fine regulaminu Sejmu dostarcza wykładnia historyczna. Przytoczyć tu należy dwie wypowiedzi, stanowiące uzasadnienie tej regulacji i obrazujące jej kontekst.

2 Słownik języka polskiego, t. 4, red. M. Bańko, Warszawa 2007, s. 419. 
Poseł D. Grabowski stwierdził na pierwszym posiedzeniu Sejmu III kadencji w dniu 21 października 1997 r., że: Ruch Odbudowy Polski jest kołem w parlamencie i jako koło nie ma swojego reprezentanta w Prezydium Sejmu. Nie ma także, zgodnie z regulaminem, który obowiązuje, swojego reprezentanta $w$ Konwencie Seniorów. Sądzę, że warto przypomnieć, że pomimo niewielkiej liczby posłów w parlamencie oddano na nas przeszło 5\% głosów. Zatem jest to duża liczba wyborców. Jeśli obecny parlament ma być reprezentatywny, a przecież o to nam wszystkim cho$d z i$, to uważam, że reprezentant koła Ruchu Odbudowy Polski winien być właczony do Konwentu Seniorów. Taki wniosek składamy dzisiaj i będziemy o to wnosili w czasie prac Komisji Nadzwyczajnej ${ }^{3}$. Z kolei poseł W. Włodarczyk na posiedzeniu Sejmu w dniu 28 października 1997 r. stwierdził, że: Artykuł 16 ust. 1 regulaminu mówi, że w skład Konwentu Seniorów wchodza przedstawiciele klubów oraz porozumień kół poselskich. Rozumiem, że taka regulacja jest potrzebna, że taka sytuacja podziału klubów i wyłonienia się z nich kół może nastąpić w przyszłości. I rzeczywiście takie zabezpieczenie $w$ regulaminie wydaje się sensowne i konieczne. Chciałbym jednak zwrócić uwagę, że poprawka, którą chcemy w tej chwili zgłosić, dotyczy czegoś innego. Uważamy, że członkami Konwentu Seniorów powinni być przewodniczacy kól parlamentarnych, które reprezentują określona listę wyborczą. Tak właśnie jest w przypadku Ruchu Odbudowy Polski. Weszliśmy do Sejmu z listy Ruchu Odbudowy Polski. Reprezentujemy ponad pót miliona wyborców... ${ }^{4}$.

Co do praktyki parlamentarnej w zakresie stosowania analizowanej regulacji, to stwierdzić można, że nie jest ona bogata. Jedynie w III kadencji Sejmu w składzie Konwentu Seniorów zasiadał - na podstawie art. 15 ust. 1 in fine regulaminu Sejmu - przedstawiciel koła poselskiego ${ }^{5}$. W praktyce pojawił się problem, czy zmiany w składzie osobowym tego koła w trakcie kadencji wpływają na jego uprawnienie do „delegowania” przedstawiciela do Konwentu Seniorów. Co do zasady przyjęto, że wpływu takiego nie $\mathrm{ma}^{6}$.

Dla wykładni systemowej pewne znaczenie przyznać należy art. 14 regulaminu Sejmu, który określa ogólnie charakter i podstawową funkcję Konwentu Seniorów. Zgodnie z tym przepisem organ ten zapewniać ma współdziałanie klubów w sprawach związanych $z$ działalnościa i tokiem prac Sejmu. Uzasadnia to założenie, że podstawowy skład Konwentu tworzą przedstawiciele klubów, a zatem

$3 \quad$ Http://orka2.sejm.gov.pl/Debata3.nsf [dostęp 21 października 2019 r.].

4 Wypowiedź posła W. Włodarczyka na pierwszym posiedzeniu Sejmu III kadencji w dniu 28 października 1997 r., http://orka2.sejm.gov.pl/Debata3.nsf [dostęp 19 października 2019 r.].

5 Zob. M.A. Kamiński, Rola Konwentu Seniorów w Sejmie RP na tle porównawczym [w:] Ustrój państwa. Myśl polityczno-prawna. Wspótczesne systemy rząów. Prace ofiarowane prof. zw. nauk prawnych Adamowi Jamrozowi z okazji Jego Jubileuszu, red. S. Bożyk, A. Olechno, Białystok 2018, s. 133.

6 M. Zubik, Uwaga 6 do art. 15 [w:] Komentarz do regulaminu Sejmu, red. A. Szmyt, Warszawa 2018, s. 89. 
wynikające $\mathrm{z}$ analizowanej regulacji uprawnienie niektórych kół ma charakter wyjątkowy ${ }^{7}$, a wobec tego nie można interpretować go w sposób rozszerzający (również w aspekcie podmiotowym).

Aby rozwiązać problem opisany we wstępie opinii, potrzebne jest dokonanie wykładni łączących się z sobą dwóch sformułowań: „koło parlamentarne reprezentujące listę wyborczą” oraz „osobnej listy wyborczej”. Poza tym wyjaśnienia wymaga znaczenie odwołania się do dnia rozpoczęcia kadencji Sejmu.

Wspomniany wcześniej kontekst historyczny nakazuje przyjęcie, że pojęciu „reprezentowania osobnej listy wyborczej” nadać należy przede wszystkim znaczenie personalne, a nie programowo-polityczne. Powinno ono być rozumiane jako wymóg przynależności do danego koła wyłącznie posłów, którzy umieszczeni byli na listach kandydatów do Sejmu zgłoszonych przez ten sam komitet wyborczy (niezależnie od statusu tego komitetu, a więc od tego, czy został utworzony przez partię polityczną, koalicję partii politycznych czy też wyborców). Inaczej mówiąc, pojęcie listy wyborczej w rozumieniu art. 15 ust. 1 regulaminu Sejmu oznacza zbiorcze określenie wszystkich list kandydatów na posłów zgłoszonych przez jeden komitet wyborczy. Powoduje to w praktyce, że jeśli w składzie osobowym danego koła (w dniu rozpoczęcia kadencji Sejmu) znalazłaby się choćby jedna osoba, która znajdowała się na liście kandydatów do Sejmu zgłoszonych przez inny komitet wyborczy, to koło takie traci automatycznie uprawnienie do „przedstawicielstwa” w Konwencie Seniorów. Ustalenie to nawiązuje do językowego znaczenia przymiotnika osobny, który oznacza „rzeczy oddzielone od innych lub od siebie nawzajem” albo też „różne rzeczy, sprawy lub osoby”. Jeżeli koło skupia posłów, którzy wybrani zostali z list różnych komitetów wyborczych, to jako całość oczywiście nie może być ono traktowane jako reprezentacja osobnej listy wyborczej (w podanym wcześniej znaczeniu), niezależnie od relacji ilościowej między posłami wybranymi z list różnych komitetów wyborczych. Taki kierunek interpretacji potwierdza wykładnia historyczna. W przytoczonych wcześniej wypowiedziach zwracano bowiem wyraźnie na uwagę na to, że posłowie tworzący koło Ruchu Odbudowy Polski wybrani zostali do Sejmu z list kandydatów tylko jednego komitetu wyborczego.

Pojawia się jednak pytanie, czy zastosowanie art. 15 ust. 1 in fine regulaminu Sejmu wymaga przynależności do określonego koła wszystkich posłów wybranych z list określonego komitetu wyborczego, czy też wystarczający jest akces tylko pewnej ich części. W literaturze wyrażono pogląd, który stanowić może podstawę rozstrzygnięcia tej kwestii. Stwierdza się mianowicie, że koło reprezentuje osobną listę wyborczą, jeżeli: członkowie tego koła dostali się do Sejmu ze wspólnej listy wyborczej - odrębnej od list z których uzyskali mandat posłowie

M. Zubik, Uwaga 6 do art. 15, op. cit., s. 89.

$8 \quad$ Stownik języka polskiego, t. 3, op. cit., s. 395. 
tworzacy pozostałe kluby $i$ koła $a^{9} \mathrm{Z}$ tak sformułowanych założeń wynika, że prawidłowy jest drugi z przedstawionych wcześniej wariantów, a więc również koło, do którego należą tylko niektórzy posłowie wybrani do Sejmu z list kandydatów jednego komitetu wyborczego, nabywa uprawnienie do udziału jego przedstawiciela w pracach (posiedzeniach) Konwentu Seniorów. Wobec wspomnianych wcześniej niejasności co do pojęcia „reprezentowania listy wyborczej” trudno na jego podstawie sformułować wymaganie zgodne z pierwszą z przedstawionych wcześniej alternatyw.

Powyższe ustalenia wymagają jednak pewnego uzupełnienia. W praktyce może wystąpić sytuacja, w której część posłów wybranych z list kandydatów jednego komitetu wyborczego tworzy na początku kadencji Sejmu koło poselskie, ale część przystępuje do klubów lub kół wraz z posłami wybranymi z list innych komitetów wyborczych. W świetle przytoczonego wcześniej poglądu doktrynalnego (a dokładnie drugiej jego części) należałoby przyjąć, że w takiej konkretnej sytuacji do koła poselskiego nie ma zastosowania art. 15 ust. 1 regulaminu Sejmu. Koło nie zrzesza bowiem posłów, którzy: dostali się do Sejmu z listy odrębnej od list, z których uzyskali mandat posłowie tworzacy pozostałe kluby $i$ koła.

Wydaje się jednak, że stanowisko takie nie jest trafne. Przytoczony wyżej pogląd (traktowany dosłownie) stanowi nadmierną generalizację i jest zbyt daleko idący. Jeżeli bowiem przyjąć kryterium „jednorodności personalnej” dla oceny reprezentatywności koła wobec konkretnej listy wyborczej, to logiczne byłoby założenie, że koła lub kluby, w skład których wchodzą posłowie wybrani z list kandydatów różnych komitetów wyborczych, nie reprezentują żadnej konkretnej „listy wyborczej”. Stąd też ich powstanie nie powinno co do zasady wpływać na kwalifikację z tego punktu widzenia koła poselskiego założonego przez innych posłów. Takie podejście nawiązuje też do zarysowanej wcześniej praktyki, która opierała się na założeniu, że zmiana „przynależności frakcyjnej” w toku kadencji nie wpływa na status koła (naturalnie z wyjątkiem sytuacji, gdy jego liczebność spadnie poniżej 3 posłów). Z uwagi jednak na ogólnikowość i niejasność regulacji cały problem trudno jednoznacznie rozstrzygnąć.

Niezależnie od powyższych wątpliwości, przyjąć należy, że jeśli niektórzy posłowie wybrani z list kandydatów danego komitetu wyborczego są (w dniu rozpoczęcia pierwszego posiedzenia Sejmu w nowej kadencji) tzw. posłami niezrzeszonymi, to pozostali członkowie izby poselskiej, którzy uzyskali mandat z tych list, mogą założyć koło ze skutkiem opisanym w art. 15 ust. 1 regulaminu Sejmu.

Odwołanie do rozpoczęcia kadencji Sejmu traktować należy jako nawiązanie do art. 98 ust. 1 Konstytucji. Zgodnie z tym przepisem kadencja Sejmu rozpoczyna się z dniem zebrania się Sejmu na pierwsze posiedzenie, zwołane przez

9 J.K. Sokołowski, Organizacja wewnętrzna, tryb i zasady funkcjonowania organów ustawodawczych [w:] Wybrane aspekty funkcjonowania Sejmu w latach 1997-2007, red. J.K. Sokołowski, P. Poznański, Kraków 2008, s. 49. 
Prezydenta RP. W kontekście praktyki wielodniowych pierwszych posiedzeń Sejmu zauważyć należy, że art. 15 ust. 1 in fine odnosi się do dnia oznaczonego w postanowieniu Prezydenta określającym datę pierwszego posiedzenia Sejmu, o ile - co jest raczej teoretyczne - z jakichś nadzwyczajnych przyczyn Sejm nie zebrałby się na posiedzenie w tym dniu. Znaczenie daty pierwszego posiedzenia Sejmu odnosi się do „reprezentacyjnego” charakteru danego koła wobec „listy wyborczej”. Łączy się ściśle z niedopuszczalnością: wprowadzenia do Konwentu przedstawicieli tzw. kół rozłamowych powstałych $w$ toku kadencji przez odejście kilku posłów z większego klubu (lub wyjątkowo koła), nawet jeśli zostali oni wybrani z list kandydatów jednego komitetu wyborczego. Czyni jednak: dopuszczalna praktykę polegająca na włączeniu do utworzonego na początku kadencji koła posłów, którzy należeli na początku kadencji do innych klubów lub kót, jak również posłów niezrzeszonych ${ }^{10}$. Należy jednak podkreślić, że niekiedy praktyka ta jest stawiana pod znakiem zapytania ${ }^{11}$.

Konsekwencją wyraźnego odwołania się w art. 15 ust. 1 regulaminu Sejmu do dnia rozpoczęcia kadencji Sejmu istotny jest - z „chronologicznego” punktu widzenia - wymóg istnienia (utworzenia) koła najpóźniej w tym dniu. Niezależnie od wspomnianych wcześniej wątpliwości co do rozumienia pojęcia reprezentowania, oczywiste jest, że koło, które powstało w terminie późniejszym, nie mogło nikogo reprezentować $\mathrm{w}$ dniu rozpoczęcia kadencji. Wymóg reprezentatywności odniesiony został przy tym wyraźnie do samego koła, a nie do posłów, którzy do niego należą. Jeśli chodzi o ustalenie daty powstania koła, to podzielić należy w pełni pogląd, że jest nią dzień ukonstytuowania się koła. Najczęściej będzie to dzień pierwszego posiedzenia jego członków ${ }^{12}$. Sama data złożenia zawiadomienia, o którym mowa w art. 8 ust. 7 regulaminu Sejmu, nie ma w tym wypadku rozstrzygającego znaczenia.

Nawiązując do dominującego w doktrynie prawa konstytucyjnego poglądu, w myśl którego datą nabycia mandatu parlamentarnego jest dzień ogłoszenia wyników wyborów ${ }^{13}$, stwierdzić należy, że koło poselskie (czy koło parlamentarne) powstać może przed dniem pierwszego posiedzenia Sejmu nowej kadencji. Co prawda, sprawowanie mandatu parlamentarnego zaczyna się od momentu złożenia ślubowania (art. 104 ust. 2 Konstytucji RP), ale zgodnie z utrwaloną praktykę pewne działania związane $\mathrm{z}$ wykonywaniem mandatu mogą być podejmowane przez posłów już wcześniej. Zalicza się do nich m.in. działalność we frakcjach

$10 \quad$ Ibidem, s. 49.

11 Zob. M. Zubik, Organizacja wewnętrzna Sejmu RP, Warszawa 2003, s. 257.

12 J.M. Karolczak, Data utworzenia klubu lub koła poselskiego [w:] Regulamin Sejmu w opiniach Biura Analiz Sejmowych, wybór i oprac. W. Odrowąż-Sypniewski, t. I, Warszawa 2010, s. 60.

13 K. Grajewski, J. Stelina, P. Uziębło, Komentarz do ustawy o wykonywaniu mandatu posła i senatora, Warszawa 2014, s. 33. 
parlamentarnych ${ }^{14}$. Granicą jest jednak dzień oficjalnego ogłoszenia wyników wyborów.

Odnosząc się do konkretnego problemu powstania dwóch (lub więcej) kół poselskich, które zrzeszają (wyłącznie) posłów wybranych z list jednego komitetu wyborczego, stwierdzić należy, że teoretycznie dopuszczalne wydają się cztery rozwiązania. Po pierwsze, przyjęcie, że koło reprezentuje osobną listę wówczas, gdy posłowie wybrani z list konkretnego komitetu są członkami jednego koła, a zatem w sytuacji utworzenia przez nich większej liczby kół żadne z nich nie jest uprawnione do wskazania przedstawiciela wchodzącego w skład Konwentu Seniorów. Po drugie, potencjalnie możliwe wydaje się zastosowanie wówczas kryterium ilościowego, tj. za reprezentatywne uznawać należałoby koło o większej liczbie członków (a dokładnie liczbie posłów wybranych z list kandydatów jednego komitetu wyborczego). Po trzecie, odwołać można się do kryterium „tożsamości politycznej”, co w praktyce oznacza, że należałoby ustalać, które z kół pozostaje w najbliższym związku z komitetem wyborczym, a w szczególności z partią polityczną, która go utworzyła. Po czwarte, można byłoby nawiązać do zasady prior tempore potior iure (pierwszeństwo w czasie daje lepsze prawa) i stwierdzić, że w analizowanej sytuacji decydować powinna data powstania poszczególnych kół poselskich (parlamentarnych).

W literaturze wyrażono pogląd, że w art. 15 ust. 1 regulaminu Sejmu: chodzi oczywiście o sytuacje, w której istnieje tylko jedno koło reprezentujące dana liste wyborcza $q^{15}$. Oznacza to wybór pierwszego z zarysowanych wcześniej wariantów. Pogląd ten opiera się, po pierwsze, na interpretacji pojęcia „osobnej listy wyborczej" i przyjęciu, że oznacza ono, iż w skład Konwentu nie może wchodzić więcej niż jeden przedstawiciel kół reprezentujących (w omówionym wcześniej aspekcie personalnym) tę samą „listę wyborczą”. Takie podejście wydaje się uzasadnione dążeniem do nadania sformułowaniu „osobna lista wyborcza” innego (szerszego) znaczenia niż określeniu „jedna lista wyborcza”. Po drugie, powołać się można na argumenty natury funkcjonalnej. Otóż przyjęcie, że posłowie wybrani z list jednego komitetu wyborczego w liczbie co najmniej 6 mogliby tworzyć dwa (a w przypadku wyboru więcej niż 8 posłów nawet trzy) koła, które reprezentowały jedną listę, prowadziłoby do tego, że mogłyby w ten sposób „sztucznie” zwiększać swoją reprezentację w Konwencje Seniorów. Byłoby to systemowo trudne do pogodzenia z założeniem „dominującej” roli klubów (poselskich i parlamentarnych) w Konwencie Seniorów. Stąd też przyjąć należy, że w sytuacji, gdy posłowie wybrani $z$ list kandydatów jednego komitetu wyborczego utworzyliby (według stanu na dzień zwołania pierwszego posiedzenia Sejmu) dwa koła poselskie (lub więcej), to art. 15 ust. 1 nie ma zastosowania do żadnego $\mathrm{z}$ nich.

14 Ibidem, s. 31.

15 J.K. Sokołowski, Organizacja wewnętrzna, op. cit., s. 49, przypis 60. 
Zwrócić można uwagę, że analogicznie ocenić należy sytuację, w której część posłów wybranych z list kandydatów określonego komitetu utworzyła klub (poselski lub parlamentarny), a część koło poselskie. Koła takiego nie można uznać za reprezentujące osobną „listę wyborczą”.

W kontekście przedstawionych wcześniej czterech wariantów rozwiązania analizowanego problemu stwierdzić należy przede wszystkim, że brak jest podstaw normatywnych, które jednoznacznie wskazywałyby na trafność któregoś z tych wariantów. Ocena z punktu widzenia liczebności kół może wpływać ewentualnie tylko na stopień reprezentatywności względem „listy wyborczej”, ale trudno byłoby tylko na tej podstawie odmówić zastosowania art. 15 ust. 1 regulaminu Sejmu. Poza tym ze względów praktycznych zastosowanie tego kryterium wymagałoby i tak przyjęcia dodatkowej reguły, która dotyczyłaby sytuacji równej liczebności konkretnych kół. Z kolei odwołanie się do „tożsamości politycznej” musiałoby obejmować wskazanie w miarę jednoznacznych kryteriów oceny, aby uniknąć zarzutu arbitralnej oceny. Oczywiście ich sformułowanie byłoby trudne, a w każdym razie nie można odnaleźć ich w przepisach regulaminu Sejmu. Wreszcie posłużenie się regułą prior tempore potior iure pozornie przyniosłoby jednoznaczne wyniki, ale i tak normatywnego sprecyzowania wymagałoby ustalenie, czy liczy się moment utworzenia koła (i co konkretnie pojęcie to oznacza), czy też moment wypełnienia przez koło obowiązku, o którym mówi art. 8 ust. 7 regulaminu Sejmu.

Wobec powyższego wspomniane wcześniej potencjalne sposoby rozwiązania analizowanego w tej części opinii problemu uznać można tylko za wskazówki dla ewentualnego jednoznacznego jego rozstrzygnięcia w drodze nowelizacji regulaminu Sejmu.

W końcowej części opinii należy zwrócić uwagę na najważniejsze zagadnienia proceduralne. Po pierwsze, nie ulega wątpliwości, że zastosowanie art. 15 ust. 1 in fine wymaga wykonania przez władze określonego koła obowiązku podania do wiadomości Marszałka Sejmu składu koła oraz jego statutu (regulaminu) wewnętrznego (art. 8 ust. 7 regulaminu Sejmu). Zawiadomienie takie może zostać złożone także po dniu, w którym rozpoczęła się kadencja Sejmu, jednak w takiej sytuacji wynikać z niego powinno, że koło istniało już w tym dniu. Władze koła nie muszą stawiać formalnego wniosku o włączenie jego przedstawiciela w skład Konwentu Seniorów, jednak względy pewności prawnej wymagały wyraźnego wskazania lub zawiadomienia (ewentualnie w statucie lub regulaminie koła), który konkretnie poseł ma być jego przedstawicielem w Konwencie Seniorów. W odróżnieniu od klubów poselskich Marszałek Sejmu nie podejmuje żadnego odrębnego rozstrzygnięcia w sprawie uznania kompetencji danego koła do „delegowania” przedstawiciela w Konwencie Seniorów lub też odmowy stwierdzenia tego uprawnienia. Jego ocena wyraża się przez tzw. czynności konkludentne, tj. zawiadamianie konkretnego posła (względnie samego koła) o zwołaniu posiedzenia Konwentu i dopuszczeniu go do udziału w nim. W sytuacjach wątpliwych 
Marszałek Sejmu może ewentualnie zapraszać przedstawiciela konkretnego koła na posiedzenia Konwentu na podstawie art. 15 ust. 3 regulaminu Sejmu. Przed rozstrzygnięciem kwestii reprezentacji Marszałek może zwrócić się o opinię do Prezydium Sejmu i Komisji Regulaminowej, Spraw Poselskich i Immunitetowych, do której należą sprawy wykładni i stosowania regulaminu Sejmu (pkt 28 załącznika do regulaminu Sejmu - Przedmiotowy zakres działania komisji sejmowych).

Gdy Marszałek Sejmu stwierdził, że przedstawiciel określonego koła nie ma prawa brania udziału w pracach Konwentu Seniorów, władzom tego koła lub jego członkom nie przysługują żadne formalne środki odwoławcze.

\section{Podsumowanie}

- Pojęcie „koła parlamentarnego reprezentującego w dniu rozpoczęcia kadencji Sejmu osobną listę wyborczą" (art. 15 ust. 1 regulaminu Sejmu) obejmuje zrzeszenia, które spełniać muszą łącznie następujące warunki:

a) zostały utworzone najpóźniej w dniu, w którym odbywa się pierwsze posiedzenie (a dokładniej w dniu, na który Prezydent RP zwołał pierwsze posiedzenie Sejmu); data powiadomienia Marszałka o składzie osobowym koła i jego statucie nie ma rozstrzygającego znaczenia,

b) składają się z co najmniej trzech posłów, członkostwo senatorów jest dopuszczalne,

c) wszyscy posłowie tworzący dane koło zostali wybrani z list kandydatów zgłoszonych przez ten sam komitet wyborczy,

d) pozostali posłowie, wybrani z list kandydatów zgłoszonych przez ten komitet wyborczy, nie utworzyli (do dnia zebrania się Sejmu na pierwsze posiedzenie) innego klubu lub koła poselskiego.

- Spełnienie powyższych warunków wynikać powinno z podanych do wiadomości Marszałka Sejmu informacji o składzie osobowym koła oraz jego regulaminu (statutu). Dopełnienie tego „obowiązku informacyjnego" jest konieczne dla udziału przedstawiciela określonego koła w posiedzeniach Konwentu Seniorów. Przedstawicielem koła nie musi być jego przewodniczący lub wiceprzewodniczący, chyba że statut (regulamin) koła ustanawia taki wymóg.

- W sytuacji, gdy posłowie wybrani z list kandydatów jednego komitetu wyborczego utworzą (według stanu na dzień zwołania pierwszego posiedzenia Sejmu) dwa lub więcej kół poselskich, to art. 15 ust. 1 nie ma zastosowania do żadnego z nich. Przyjąć należy, że nie reprezentują one wówczas osobnej „listy wyborczej”. - W kontekście poważnych wątpliwości interpretacyjnych zasygnalizować należy potrzebę dokonania nowelizacji art. 15 ust. 1 regulaminu Sejmu (w części końcowej) i dostosowania go do obowiązujących przepisów ustawowych z zakresu prawa wyborczego albo sprecyzowania jego treści w drodze uchwały interpretacyjnej Prezydium Sejmu (art. 12 pkt 3 regulaminu Sejmu). 


\section{Bibliografia}

Grajewski K., Stelina J., Uziębło P., Komentarz do ustawy o wykonywaniu mandatu posła i senatora, Warszawa 2014.

Kamiński M.A., Rola Konwentu Seniorów w Sejmie RP na tle porównawczym [w:] Ustrój państwa. Myśl polityczno-prawna. Wspótczesne systemy rzadów. Prace ofiarowane prof. zw. nauk prawnych Adamowi Jamrozowi z okazji Jego Jubileuszu, red. S. Bożyk, A. Olechno, Białystok 2018.

Karolczak J.M., Data utworzenia klubu lub koła poselskiego [w:] Regulamin Sejmu w opiniach Biura Analiz Sejmowych, wybór i oprac. W. Odrowąż-Sypniewski, t. I, Warszawa 2010.

Słownik języka polskiego, t. 3, t. 4, red. M. Bańko, Warszawa 2007.

Sokołowski J.K., Organizacja wewnętrzna, tryb i zasady funkcjonowania organów ustawodawczych [w:] Wybrane aspekty funkcjonowania Sejmu w latach 1997-2007, red. J.K. Sokołowski, P. Poznański, Kraków 2008.

Zubik M., Organizacja wewnętrzna Sejmu RP, Warszawa 2003.

Zubik M., Uwaga 6 do art. 15 [w:] Komentarz do regulaminu Sejmu, red. A. Szmyt, Warszawa 2018. 